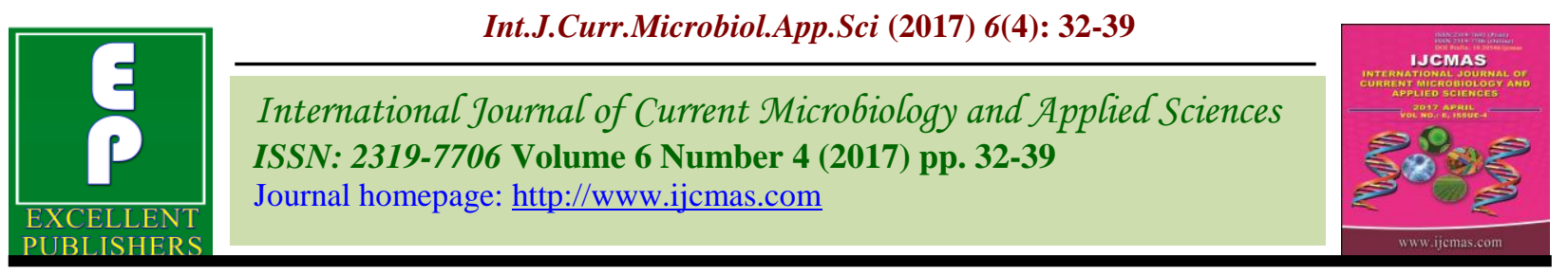

Original Research Article https://doi.org/10.20546/ijcmas.2017.604.005

\title{
Growth performance of Thorn less Bamboos (Bambusa balcooa Roxb. and Bambusa vulgaris Schrader ex J. C. Wendland)
}

\author{
N. Krishnakumar*, S. Umesh Kanna, K.T. Parthiban and M. Preethi Shree \\ Forest College and Research Institute, TNAU, Mettupalayam, India \\ *Corresponding author
}

A B S T R A C T

\begin{tabular}{|l|}
\hline Ke y w o r d s \\
Bambusa balcooa, \\
Bambusa vulgaris, \\
Agro climatic zones \\
Biometric attributes. \\
\hline Article Info \\
\hline Accepted: \\
02 March 2017 \\
Available Online: \\
10 April 2017 \\
\hline
\end{tabular}

Studies were undertaken to elicit information on performance of Bambusa balcooa and Bambusa vulgaris across five agro climatic regions as well as different age gradations, association among the biometric attributes. Bambusa balcooa proved its significant phenotypic superiority in terms of all the biometric attributes studied. The performance of Bambusa balcooa across the agro climatic regions viz., North Eastern Zone, Northern Zone, Western Zone, Cauvery Delta Zone and Southern Zone was also consistent and higher than the Bambusa vulgaris and Bambusa bambos.

\section{Introduction}

One of the most unique and versatile groups of plants known to mankind, the bamboos occupy a special place in the lives of the rural, especially in Asia. Often called the giant grass, the graceful weaving stalks give it, an enchanting appearance. Bamboo is known as 'poor man's timber', 'the cradle to coffin plant' and 'green gold'. More recently, bamboo has been called the "wonder plant" (INBAR, 2004), the "miracle grass" (ETI PROSEA, 2001) and the "raw materials of the $21^{\text {st }}$ century". The plant shakes violently by the storm, bends but never breaks. Many bamboo species have high utilization value with more than 1500 documented uses. Bamboos play an important role in local economies and their commercial importance is growing at national and international level (Bystriakova et al., 2004).
Bamboos are the most important items of forest produce used by the rural communities in Asia and the Pacific. Bamboos are woody perennial evergreen monocotyledonous having considerable economic, social and ecological importance. Woody bamboo belongs to the tribe Bambuseae that comprise 9 to 10 sub tribes, containing between 59 and 111 genera and at least 1447 species (Ohrnberger, 1999). The diversity observed within this group of plants is huge, ranging from very small members up to tall stately individuals measuring over $30 \mathrm{~m}$ tall. About 300 species are so far reported from China, 130 species from India, 55 species from the Philippines, 50 species from Thailand, 33 species from Bangladesh, 31 species from Indonesia, 26 species from Papua New Guinea and 12 species from Malaysia 
(Sharma, 1987). The largest forest area under bamboos is in India with 9.57 million hectares of bamboo forests or 12.8 per cent of the total forest area. The major bamboos are Dendrocalamus strictus and Bambusa bambos with an overall annual production of 5 million tons. Above the productivity of bamboo is increased through tree outside forest as a source of paper industries, poles, handicrafts, cottage industries and etc., For that purposes, the productivity performance of different agroclimatic zone as well as age gradation of thorn less bamboos viz., Bambusa balcooa and Bambusa vulgaris are evaluated and present hereunder.

\section{Materials and Methods}

The thorn less bamboos species viz., Bambusa balcooa and Bambusa vulgaris grown in five agro climatic viz., Western Zone, Northern Zone, North Eastern Zone, Cauvery Delta Zone and Southern Zone were chosen as the experimental material for the present study. From the each agro climatic regions, one year, two year, three year, four year and five year old plantations of Bambusa balcooa and Bambusa vulgaris were selected. From each plantation, 25 clumps in three replications were selected for recording the biometric observations viz., height, diameter, number of culms and internodal length. Similarly, Bambusa bambos was also deployed for recording the biometric observations across the age gradations as well as agro climatic regions. These observations were used to compare the performance of thorn less bamboos viz., Bambusa balcooa and Bambusa vulgaris and assess its superiority over thorn bamboo.

\section{Estimation of biometric attributes}

The observations were recorded from the first year, second year, third year, fourth year and fifth year old Bambusa vulgaris and Bambusa balcooa plantations established in the five agro climatic regions of Tamil Nadu viz., Western Zone, Northern Zone, North Eastern Zone, Cauvery Delta Zone and Southern Zone. The following biometric attributes were recorded as detailed below.

\begin{tabular}{|l|l|l|}
\hline & & $\begin{array}{l}\text { The plant height was } \\
\text { measured from ground } \\
\text { level to the tip of the } \\
\text { stem and expressed in } \\
\text { meter. }\end{array}$ \\
\hline Diameter & $: \begin{array}{l}\text { Diameter was measured } \\
\text { at breast height at 1.37 m } \\
\text { height from the base of } \\
\text { the culm and expressed } \\
\text { in cm. }\end{array}$ \\
\hline $\begin{array}{l}\text { Number } \\
\text { of Culms }\end{array}$ & $: \begin{array}{l}\text { The number of culms } \\
\text { was counted and } \\
\text { expressed in number. }\end{array}$ \\
\hline $\begin{array}{l}\text { Internodal } \\
\text { Length }\end{array}$ & $: \begin{array}{l}\text { The internodal length was } \\
\text { measured in between two } \\
\text { nodes of a culm and } \\
\text { expressed in cm. }\end{array}$ \\
\hline
\end{tabular}

\section{Statistical analysis}

The data gathered from nursery and field experiments were analysed and tabulated. Estimates of mean, variance and standard error were worked out as per the procedure described by Panse and Sukhatme (1978). The significance test was carried out by referring to the standard ' $F$ ' table of Snedecor (1961).

\section{Results and Discussion}

The present investigation was carried out in five agro climatic regions of Tamil Nadu viz., North Eastern Zone, Northern Zone, Western Zone, Cauvery Delta Zone and Southern Zone with two thorn less bamboo species viz., Bambusa balcooa and Bambusa vulgaris across different age gradations in order to elucidate the suitability of thorn less bamboos based on their growth performance. The 
growth performance of Bambusa bambos was used for comparison. The results of statistically analyzed data are presented here under. The results of biometric attributes of Bambusa balcooa and Bambusa vulgaris over age gradations and in agro climatic regions are as follows.

\section{Height}

Significant variation in height at one percent level was observed among the thorn less bamboos viz., Bambusa balcooa and Bambusa vulgaris across the age gradation as well as agro climatic regions. The highest grand general mean over five years was recorded by Bambusa balcooa $(7.39 \mathrm{~m})$. The percent increase in height of Bambusa balcooa over Bambusa vulgaris was (17.4\%). Whereas the per cent increase of height over Bambusa bambos was $30.6 \%$. With respect agro climatic region wise performance, Bambusa balcooa exceled in height growth significantly and consistently over all the agro climatic regions in the order of Western Zone $(8.10 \mathrm{~m})$ followed by Northern Zone $(7.51 \mathrm{~m})$ and Southern Zone $(7.40 \mathrm{~m})$. However, Bambusa vulgaris registered only $6.84 \mathrm{~m}$ and $5.46 \mathrm{~m}$ and $4.46 \mathrm{~m}$ in Western Zone, Northern Zone and Southern Zone respectively (Table 1). Regarding age gradation wise height performance, Bambusa balcooa exhibited consistent and significant superiority over Bambusa vulgaris and Bambusa bambos at all the age gradations.

\section{Diameter}

This trait registered significant highest grand general mean of $5.42 \mathrm{~cm}$ in Bambusa balcooa over five years of growth period in five agro climatic regions. However, Bambusa vulgaris registered only $4.61 \mathrm{~cm}$ as grand general mean. The percentage increase in diameter over Bambusa bambos was 16.8 percentage and over Bambusa vulgaris was 8.10 percentage.
The Bambusa balcooa recorded significant and constant higher diameter performance over Bambusa vulgaris in all the agro climatic regions. Among the five agro climatic regions, the significant maximum diameter growth was recorded in Southern Zone (5.72 $\mathrm{cm})$ followed by Western Zone $(4.82 \mathrm{~cm})$ and Cauvery Delta Zone $(4.74 \mathrm{~cm})$.

The minimum diameter growth was observed in Northern Zone $(3.38 \mathrm{~cm}$ ) (Table 2). The diameter growth across the age gradations as well as among the thorn less bamboo species was significant at one per cent level. Across the age gradations, Bambusa balcooa registered its consistent superiority over Bambusa vulgaris as well as Bambusa bambos.

\section{Numbers of culms}

A significant variation in number of culms was observed at five per cent level among the thorn less bamboo species. The highest grand general mean of 19.44 culms was registered by Bambusa balcooa followed by Bambusa vulgaris (19.22). The Bambusa bambos recorded only 14.89 culms as its grand general mean.

The Bambusa balcooa exhibited 0.22 percentage increase in number of culms over Bambusa vulgaris across the age gradations as well as agro climatic regions. But the observed per cent increase in number of culms over Bambusa bambos was 4.55 percentage. With regard to performance in terms of number of culms under various agro climatic regions, Bambusa balcooa proved its superiority over Bambusa vulgaris. The maximum number of culms was recorded by Bambusa balcooa in Western Zone (20.16). Whereas, Bambusa vulgaris registered only 19.53 number of culms, this is 0.63 per cent increase of Bambusa balcooa over Bambusa vulgaris (Table 3 ). 
Table.1 Variations in height $(\mathrm{m})$ among the thornless bamboos across the age gradations and agro climatic regions

\begin{tabular}{|c|c|c|c|c|c|c|c|c|c|c|c|c|c|c|c|}
\hline Age & & I Year & & & II Year & & & III Year & & & IV Year & & & V Year & \\
\hline Location & B.balcooa & B.vulgaris & B.bambos & B.balcooa & B.vulgaris & B.bambos & B.balcooa & B.vulgaris & B.bambos & B.balcooa & B.vulgaris & B.bambos & B.balcooa & B.vulgaris & B.bambos \\
\hline $\begin{array}{l}\text { Western } \\
\text { zone }\end{array}$ & $6.71 * *$ & $5.86 * *$ & $3.64 *$ & $7.58^{*}$ & $6.36^{*}$ & $3.96^{*}$ & $8.22 *$ & $6.84 *$ & $4.36^{*}$ & $8.78 * *$ & 7.35 & $4.97 *$ & $9.21 * *$ & $7.83 *$ & $5.86^{* *}$ \\
\hline $\begin{array}{l}\text { Northern } \\
\text { zone }\end{array}$ & 4.75 & $5.45^{*}$ & 3.27 & 5.72 & $6.59 *$ & 3.64 & 6.75 & $7.27 * *$ & $4.59 * *$ & 7.77 & 8.04 & 4.71 & 8.79 & 8.09 & 5.45 \\
\hline $\begin{array}{l}\text { Northern } \\
\text { eastern } \\
\text { zone }\end{array}$ & $6.53^{*}$ & 4.44 & 3.47 & 7.01 & 4.95 & 3.72 & 7.52 & 5.47 & 3.95 & 8.03 & 5.98 & 4.64 & 8.50 & 6.50 & 5.26 \\
\hline $\begin{array}{l}\text { Southern } \\
\text { zone }\end{array}$ & $6.43^{*}$ & 3.46 & 3.46 & 6.97 & 3.94 & 3.66 & 7.49 & 4.46 & 3.94 & 8.00 & 4.98 & 4.59 & 8.11 & 5.48 & 5.36 \\
\hline $\begin{array}{l}\text { Cauvery } \\
\text { delta zone }\end{array}$ & 5.09 & $5.47 *$ & 3.46 & 6.09 & 5.96 & $3.94 *$ & 6.89 & 6.46 & 3.96 & 7.70 & 6.98 & $4.95 *$ & 8.53 & 7.50 & 5.47 \\
\hline Mean & 5.90 & 4.94 & 3.46 & 6.67 & 5.56 & 3.78 & 7.73 & 6.10 & 4.16 & 8.06 & 6.67 & 4.77 & 8.63 & 7.08 & 5.48 \\
\hline SEd & 0.3982 & 0.2317 & 0.0664 & 0.3390 & 0.3071 & 0.0892 & 0.2386 & 0.3268 & 0.0987 & 0.1404 & 0.3482 & 0.0809 & 0.0810 & 0.2772 & 0.1009 \\
\hline CD (0.05) & 0.8442 & 0.4911 & 0.1407 & 0.7188 & 0.6511 & 0.1892 & 0.5058 & 0.6927 & 0.2092 & 0.2976 & 0.7381 & 0.1715 & 0.1717 & 0.5877 & 0.2139 \\
\hline CD (0.01) & 1.1632 & 0.6767 & 0.1939 & 0.9903 & 0.8971 & 0.2607 & 0.6969 & 0.9544 & 0.2883 & 0.4100 & 1.0170 & 0.2363 & 0.2366 & 0.8098 & 0.2948 \\
\hline
\end{tabular}

Table.2 Variations in Diameter $(\mathrm{cm})$ among the thornless bamboos across the age gradations and agro climatic regions

\begin{tabular}{|c|c|c|c|c|c|c|c|c|c|c|c|c|c|c|c|}
\hline Age & & I Year & & & II Year & & & III Year & & & IV Year & & & V Year & \\
\hline Location & B.balcooa & B.vulgaris & B.bambos & B.balcooa & B.vulgaris & B.bambos & B.balcooa & B.vulgaris & B.bambos & B.balcooa & B.vulgaris & B.bambos & B.balcooa & B.vulgaris & B.bambos \\
\hline $\begin{array}{l}\text { Western } \\
\text { zone }\end{array}$ & $3.90 * *$ & $3.15 * *$ & $2.46 * *$ & 4.35 & $4.05^{* *}$ & 3.02 & 4.92 & $4.84 * *$ & 3.98 & $6.52 * *$ & 5.67 & 4.60 & 7.42 & 6.43 & 5.49 \\
\hline $\begin{array}{l}\text { Northern } \\
\text { Zone }\end{array}$ & $4.21 * *$ & $2.99 * *$ & 1.51 & $5.09 * *$ & $3.93 * *$ & 2.61 & $5.47 * *$ & 4.26 & 3.36 & 6.13 & 5.17 & 4.17 & 7.03 & 5.59 & 4.92 \\
\hline $\begin{array}{l}\text { Northern } \\
\text { eastern zone }\end{array}$ & 3.17 & 1.90 & 2.13 & 3.78 & 2.52 & $3.50 * *$ & 3.37 & 3.19 & $4.40 * *$ & 5.05 & 3.83 & $4.93 * *$ & 5.69 & 5.48 & 5.57 \\
\hline $\begin{array}{l}\text { Southern } \\
\text { zone }\end{array}$ & 2.07 & 1.98 & 1.74 & 4.23 & $3.95 * *$ & 2.85 & $6.23 * *$ & $5.90 * *$ & 3.79 & $8.42 * *$ & $7.88 * *$ & $4.82 *$ & $10.51 * *$ & $8.91 * *$ & 5.57 \\
\hline $\begin{array}{l}\text { Cauvery } \\
\text { delta zone }\end{array}$ & $4.16^{* *}$ & $3.47 * *$ & $2.20 *$ & 4.48 & $4.15^{* *}$ & 3.16 & $5.45 * *$ & $4.75^{* *}$ & 4.04 & 6.03 & 5.40 & 4.52 & 6.58 & 5.96 & 5.25 \\
\hline Mean & 3.50 & 2.70 & 2.01 & 4.46 & 3.72 & 3.03 & 5.29 & 4.59 & 3.91 & 6.43 & 5.59 & 4.61 & 7.45 & 6.47 & 5.36 \\
\hline SEd & 0.0570 & 0.0501 & 0.0928 & 0.0408 & 0.0553 & 0.0820 & 0.0540 & 0.0553 & 0.1461 & 0.0318 & 0.1690 & 0.0786 & 0.0363 & 0.0629 & 0.1283 \\
\hline CD (0.05) & 0.1209 & 0.1061 & 0.1967 & 0.0864 & 0.1173 & 0.1738 & 0.1145 & 0.1172 & 0.3098 & 0.0674 & 0.1333 & 0.1666 & 0.0769 & 0.3582 & 0.2721 \\
\hline CD (0.01) & 0.1666 & 0.1462 & 0.2710 & 0.1191 & 0.1616 & 0.2395 & 0.1577 & 0.1615 & 0.4268 & 0.0928 & 0.1837 & 0.2295 & 0.1059 & 0.4936 & 0.3749 \\
\hline
\end{tabular}


Table.3 Variations in Number of Culms among the bamboos across the age gradations and agro climatic regions

\begin{tabular}{|c|c|c|c|c|c|c|c|c|c|c|c|c|c|c|c|}
\hline \multirow[b]{2}{*}{ Location } & \multicolumn{3}{|c|}{ I Year } & \multicolumn{3}{|c|}{ II Year } & \multicolumn{3}{|c|}{ III Year } & \multicolumn{3}{|c|}{ IV Year } & \multicolumn{3}{|c|}{ V Year } \\
\hline & B.balcooa & B.vulgaris & B.bambos & B.balcooa & B.vulgaris & B.bambos & B.balcooa & B.vulgaris & B.bambos & B.balcooa & B.vulgaris & B.bambos & B.balcooa & B.vulgaris & B.bambos \\
\hline Western zone & 6.68 & 6.46 & 4.88 & $13.54 * *$ & 13.13 & 9.47 & $20.25 * *$ & 19.50 & 13.92 & $27.08 * *$ & 26.36 & 19.72 & $33.27 *$ & 32.20 & 24.67 \\
\hline Northern Zone & 5.93 & 6.22 & $5.27 * *$ & 12.25 & 12.77 & 9.63 & 17.97 & 19.29 & 14.34 & 24.55 & 25.43 & 19.13 & 31.20 & 31.87 & 24.10 \\
\hline $\begin{array}{l}\text { Northern } \\
\text { eastern zone }\end{array}$ & 6.37 & 6.53 & $5.29 * *$ & 12.61 & 12.76 & $10.32 * *$ & 18.99 & 19.37 & $15.58 * *$ & 25.32 & 25.84 & $20.69 * *$ & 31.52 & 32.25 & $26.30 * *$ \\
\hline Southern zone & 6.49 & 6.37 & 5.10 & 13.25 & 12.36 & $10.31 * *$ & 19.55 & 18.53 & $15.15^{* *}$ & 26.44 & 24.75 & 20.12 & 33.00 & 30.75 & 25.06 \\
\hline $\begin{array}{l}\text { Cauvery delta } \\
\text { zone }\end{array}$ & $6.81 *$ & 6.62 & 4.49 & $13.37 *$ & 13.21 & 9.57 & $19.95 * *$ & 19.57 & 14.51 & $26.85^{*}$ & 25.76 & 19.68 & $32.88 * *$ & 32.65 & 25.04 \\
\hline Mean & 6.46 & 6.44 & 5.01 & 13 & 12.85 & 9.86 & 19.34 & 19.25 & 14.70 & 26.05 & 25.63 & 19.87 & 32.37 & 31.94 & 25.03 \\
\hline SEd & 0.1490 & 0.0994 & 0.0611 & 0.1505 & 0.2345 & 0.1014 & 0.1705 & 0.2740 & 0.0581 & 0.3458 & 0.3290 & 0.1405 & 0.3785 & 0.4926 & 0.1221 \\
\hline CD (0.05) & 0.3159 & 0.2292 & 0.1296 & 0.3191 & 0.4971 & 0.2150 & 0.3615 & 0.6319 & 0.1233 & 0.7330 & 0.7586 & 0.2978 & 0.8023 & 1.1360 & 0.2588 \\
\hline CD (0.01) & 0.4353 & 0.3335 & 0.1786 & 0.4397 & 0.6849 & 0.2962 & 0.4981 & 0.9195 & 0.1698 & 1.0099 & 1.1038 & 0.4104 & 1.1055 & 1.6530 & 0.3566 \\
\hline
\end{tabular}

Table.4 Variations in Internodal Length $(\mathrm{cm})$ among the bamboos across the age gradations and agro climatic regions

\begin{tabular}{|c|c|c|c|c|c|c|c|c|c|c|c|c|c|c|c|}
\hline \multirow{2}{*}{$\begin{array}{l}\text { Age } \\
\text { Location }\end{array}$} & \multicolumn{3}{|c|}{ I Year } & \multicolumn{3}{|c|}{ II Year } & \multicolumn{3}{|c|}{ III Year } & \multicolumn{3}{|c|}{ IV Year } & \multicolumn{3}{|c|}{ V Year } \\
\hline & B.balcooa & B.vulgaris & B.bambos & B.balcooa & B.vulgaris & B.bambos & B.balcooa & B.vulgaris & B.bambos & B.balcooa & B.vulgaris & B.bambos & B.balcooa & B.vulgaris & B.bambos \\
\hline Western zone & 28.22 & 22.77 & 17.30 & 28.56 & 23.67 & 17.68 & 29.06 & 23.87 & 17.88 & 29.24 & 24.29 & 18.32 & 29.43 & 24.54 & 18.57 \\
\hline Northern Zone & $33.06 * *$ & $26.88 * *$ & 18.75 & $33.25 * *$ & $28.21 * *$ & 18.98 & $33.42 * *$ & $29.32 * *$ & 19.15 & $33.67 * *$ & $29.99 * *$ & 19.53 & $33.75 * *$ & $30.62 * *$ & 19.64 \\
\hline $\begin{array}{l}\text { Northern } \\
\text { eastern zone }\end{array}$ & 27.86 & 24.07 & $19.17 *$ & 27.96 & 24.22 & $19.39 *$ & 28.00 & 24.44 & $19.60 * *$ & 28.17 & 24.62 & $19.69 *$ & 28.35 & 24.84 & $19.98 *$ \\
\hline Southern zone & $32.79 * *$ & 23.50 & 19.14 & $32.90 * *$ & 23.62 & $19.40 *$ & $33.01 * *$ & 23.82 & $19.82 * *$ & $33.19 * *$ & 24.20 & $19.91 * *$ & $33.25 * *$ & 24.46 & $20.12 * *$ \\
\hline $\begin{array}{l}\text { Cauvery delta } \\
\text { zone }\end{array}$ & 30.41 & $26.92 * *$ & 18.92 & 30.56 & $27.07 * *$ & 19.28 & 30.62 & $27.15^{* *}$ & 19.35 & 30.68 & $27.27 * *$ & 19.56 & 30.89 & $27.43 * *$ & 19.73 \\
\hline Mean & 30.47 & 24.83 & 18.66 & 30.65 & 25.36 & 18.94 & 30.82 & 25.72 & 19.16 & 30.99 & 26.07 & 19.40 & 31.13 & 26.38 & 19.61 \\
\hline SEd & 0.2832 & 0.1710 & 0.2323 & 0.2041 & 0.3055 & 0.1950 & 0.1250 & 0.2707 & 0.1244 & 0.1245 & 0.2718 & 0.1173 & 0.2215 & 0.2849 & 0.1327 \\
\hline CD (0.05) & 0.6004 & 0.3626 & 0.4925 & 0.4327 & 0.6476 & 0.4134 & 0.2650 & 0.5738 & 0.2637 & 0.2640 & 0.5761 & 0.2486 & 0.4695 & 0.6039 & 0.2813 \\
\hline CD (0.01) & 0.8273 & 0.4996 & 0.6785 & 0.5963 & 0.8923 & 0.5696 & 0.3651 & 0.7906 & 0.3633 & 0.3638 & 0.7938 & 0.3425 & 0.6469 & 0.8321 & 0.3875 \\
\hline
\end{tabular}


Figure.1 Overall growth performance of thorn less bamboos at five year old among the different agro climatic regions

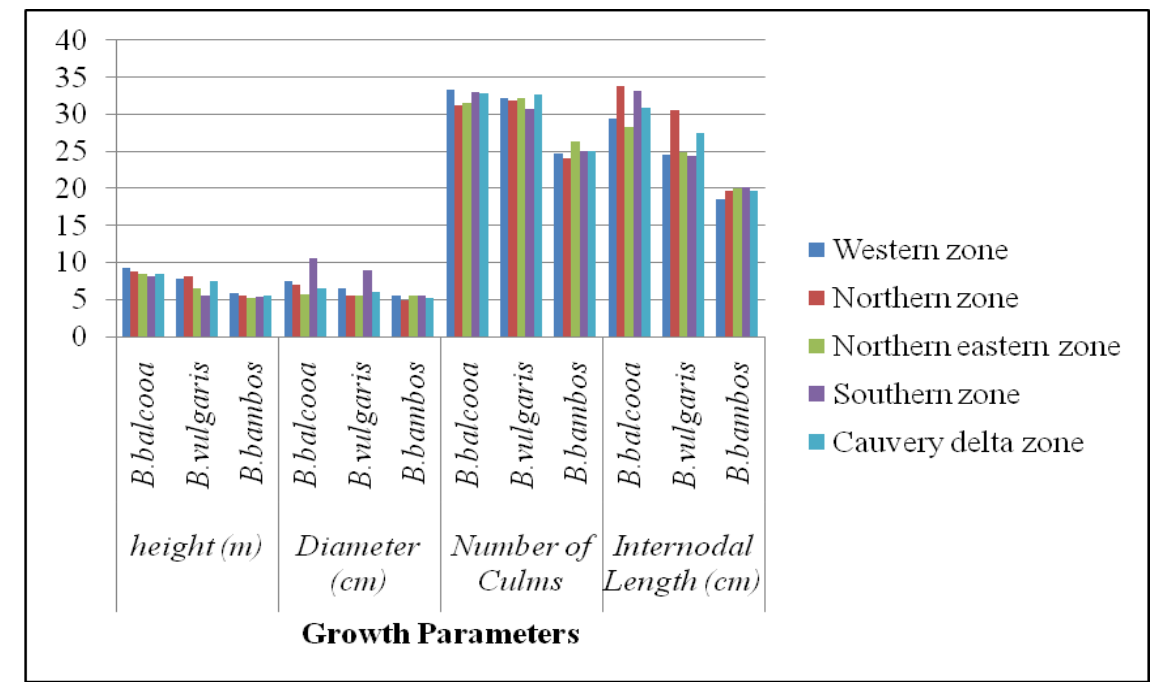

Bambusa balcooa exhibited its superiority over Bambusa vulgaris by producing maximum number of culms in first year (6.46), second year (13.00), third year (19.34), fourth year (26.05) and fifth year (32.37). However, in all these age gradations Bambusa bambos registered only minimum number of culms in the order of 5.01, 9.86, 14.70, 19.87 and 25.03 in first year, second year, third year, fourth year and fifth year respectively (Table 3 ).

\section{Internodal length}

Significant difference in internodal length at one percent level was witnessed among the thorn less bamboos viz,. Bambusa balcooa and Bambusa vulgaris across the age gradation as well as agro climatic regions. The highest grand general mean over five years was recorded by Bambusa balcooa $(30.81 \mathrm{~cm})$. The percent increase in internodal length of Bambusa balcooa over Bambusa vulgaris was $(5.14 \%)$. Whereas the per cent increase of internodal length over Bambusa bambos was 11.66 percentage. With respect agro climatic region wise performance, Bambusa balcooa shined in internodal length significantly and consistently over all the agro climatic regions in the order of North Eastern Zone $(33.43 \mathrm{~cm})$ followed by Southern Zone $(33.02 \mathrm{~cm})$ and Cauvery Delta Zone $(30.63 \mathrm{~cm})$. However, Bambusa vulgaris registered only $29.00 \mathrm{~cm}$ and $23.92 \mathrm{~cm}$ and $27.10 \mathrm{~cm}$ in North Eastern Zone, Southern Zone, and Cauvery Delta Zone respectively (Table 4). Regarding age gradation wise internodal length performance, Bambusa balcooa exhibited consistent and significant superiority over Bambusa vulgaris and Bambusa bambos at all the age gradations.

Genetic improvement of the thorn less bamboos viz., Bambusa balcooa and Bambusa vulgaris through evaluation trial under various agro climatic regions can play a very significant role in improving productivity, yields, quality of produce and profitability. Hence genetic evaluation trials were conducted at various agro climatic regions and significant differences were found across the age gradations viz., $1^{\text {st }}$ year, $2^{\text {nd }}$ year, $3^{\text {rd }}$ year, $4^{\text {th }}$ year and $5^{\text {th }}$ year as well as among different agro climatic regions for the biometric attributes such as height, diameter, number of culms, internodal length, leaf 
length and leaf width. The present study indicated that it could be possible to select potential species with greater genetic gain for commercially important traits. The largest, cheapest and fastest gains in most of the forestry tree improvement programmes will accrue if use of suitable species is assured (Zobel and Talbert, 1984).

Among the Bambusa balcooa and Bambusa vulgaris, the superiority of Bambusa balcooa was evidenced consistently in all the age gradations as well as across the agro climatic zones of Tamil Nadu. A superfluity of workers reported the existence of significant differences and superiority of few species, seed sources, progenies and provenances in various tree species like Acacia nilotica (Padmini and Banerjee, 1986). Eucalyptus tereticornis (Otegbeye, 1990), Santalum album (Bagchi and Sindhu Veerendra, 1991), Tecomella undulate (Jindal et al., 1991), Terminalia arjuna (Srivastava et al., 1993) Lagerstroemia spp. (Jamaludheen et al., 1995), Dalbergia sissoo (Rawat and Nautiyal, 2007), Pinus elliottii var. elliottii (Vergara et al., 2011), Melia dubia (Saravanan, 2012) Madhuca latifolia (Umesh Kanna et al., 2013), acacia nilotica (jeya prakash, 2000), Tectona grandis (Parthiban, 2001) Casuarina equisetifolia (Paramathma et al., 1994) bamboo species (Thiruniraiselvan, 2012), Aibizia lebbeck (Radhakrishnan, 2001), Ceiba pentandra (Rajendran, 2001) and Eucalyptus (Jude, 2005) which thus lend support to the current findings in Bambusa balcooa and Bambusa vulgaris (Figure 1).

Hence, trees growth performance could be a good indicator for the selection of best species in the evaluation programme. The present study revealed that thorn less bamboo, Bambusa balcooa would be recommended for the large scale plantation and further improvement due to their early superiority compared to Bambusa vulgaris and Bambusa bambos.
In conclusion investigations were carried out in Bambusa balcooa, Bambusa vulgaris and Bambusa bambos to access its performance across various agro climatic regions viz., North Eastern Zone, Northern Zone, Western Zone, Cauvery Delta Zone and Southern Zone as well as various age gradations. Taking a holistic view of the biometric attributes, Bambusa balcooa proved significantly superior at one per cent level for all the traits viz., height, diameter, number of culms, internodal length, leaf length and leaf width over Bambusa vulgaris and Bambusa bambos. The performance of Bambusa balcooa across the agro climatic regions viz., North Eastern Zone, Northern Zone, Western Zone, Cauvery Delta Zone and Southern Zone was consistent and higher than the Bambusa vulgaris and Bambusa bambos.

\section{References}

Bagchi, S.K. and H.C. Sindhu Veerendra. 1991. Variation and relationship in developmental growth phases of Santalum album after pruning. Indian Forester, 117: 1053-1058.

Bystriakova, N., V. Kapos and I. Lysenko. 2004. UNEP - WCM/INBAR, Cambridge.

ETI PROSEA. 2001. Bamboo: The Miracle Grass, Movie in Plant Resources of South East Asia: Rattans and Bamboos, World Biodiversity Database CD- ROM Series, Expert Centre for Taxonomic Identification, University of Amsterdam, The Netherlands.

INBAR Working Papers. 2004. International Network on Bamboo and Rattan, Beijing, China.

Jamaludheen, V., K. Gopikumar and K. Sudhakara. 1995. Variability studies in Lagerstroemia (Lagerstroemia speciosa Pers.). Indian Forester, 121(2): 137-141.

Jayaprakash, J. 2000. Studies on the genetic analysis among seed sources of Acacia nilotica (Linn.) Willd. ex. del. using biometric and biochemical approaches. 
Ph.D. Thesis, Tamil Nadu Agricultural University, Coimbatore.

Jindal, S.K., Manjit Singh, K.R. Solanki and N.L. Kachar. 1991. Variability and change in genetic parameter of height in juvenile progenies of Tecomella undulata (Sm.). J. Tree Sci., 10(1): 25-28.

Jude Sudhagar, R. 1999. Genetic analysis in Eucalyptus grandis Hill ex. Maiden and interspecific hybridization in Eucalyptus species. M.Sc. Thesis, Tamil Nadu Agricultural University, Coimbatore.

Ohrnberger, D. 1999. The Bamboos of the world, Elsevier Science, B.V. Amsterdam, The Netherlands.

Otegbeye, G.O. 1990. Provenance variation in Eucalyptus tereticornis in a field trial within the Guinea Savanna Zone of Nigeria. Silvae Genetica, 39: 103-107.

Padmini, S. and A.C. Banerjee. 1986. Provenance trails of Acacia nilotica. J. Tree Sci., 5: 53-56.

Panse, V.G. and P.V. Sukhatme. 1978. Statistical methods for Agricultural workers. ICAR Publication, New Delhi.

Paramathma, M., C. Surendran and R.S.V. Rai. 1994. Studies on heterosis in six species of Eucalyptus. J. Trop. Sci., 9(3): 345356.

Parthiban, K.T. 2001. Seed source variations, molecular characterization and clonal propagation in teak (Tectona grandis Linn f.). Ph.D. Thesis, Tamil Nadu Agricultural University, Coimbatore

Radhakrishnan, S. 2001. Genetic divergence and DNA based molecular characterization in Albizia lebbeck (L.)
Benth. Ph.D. Thesis, Tamil Nadu Agricultural University, Coimbatore.

Rajendran, P. 2001. Clonal propagation, evaluation and genetic diversity in kapok (Ceiba pentandra Linn. Gaertn.). Ph.D. Thesis, Tamil Nadu Agricultural University, Coimbatore.

Rawat, R.S. and S. Nautiyal. 2007. GenotypeSite Interactions in Growth, Physiological and Biochemical Parameters in Clones of Dalbergia Sissoo Roxb. Silvae Genetica, 56: 201-206.

Sharma, Y.K. and K.S. Bhandari. 1983. Eucalyptus for pulp and paper making. Indian Forester, 109(12): 944-968.

Snedecor, G.W. 1961, Statistical Methods, Allied Pacific Pvt. Ltd, Bombay, 534 pp.

Srivastava, D.P., P.K. Srivastav, A.K. Goel and K. Thangavelu. 1993. Correlation and path coefficient studies in Terminalia arjuna. Ann. For., (1): 178-181

Thiruniraiselvan. 2012. genetic analysis, biometric attributes and pulping characterization of bamboos. M.Sc, Thesis, Tamil Nadu Agricultural University, Coimbatore.

Umesh Kanna, S.K.T., Parthiban and S. Vennila. 2013, Seed source variation in pungam. MASU, 43-46 pp.

Vergara, R., T.L. White, D.A. Huber and R.A. Schmidt. 2011. Realized Genetic Gains of Rust Resistant Selections of Slash Pine (Pinus elliottii var. elliottii) Planted in High Rust Hazard Sites. Silvae Genetica, 56: 5.

Zobel, B.J. and J. Talbert. 1984. Applied Forest tree improvement, John Wiley \& Sons, $505 \mathrm{pp}$.

\section{How to cite this article:}

Krishnakumar, N., S. Umesh Kanna, K.T. Parthiban and Preethi Shree, M. 2017. Growth performance of Thorn less Bamboos (Bambusa balcooa Roxb. and Bambusa vulgaris Schrader ex J. C. Wendland). Int.J.Curr.Microbiol.App.Sci. 6(4): 32-39.

doi: https://doi.org/10.20546/ijcmas.2017.604.005 